Check for updates

Montreal, Canada

Cite this as: BMJ 2021;372:n153 http://dx.doi.org/10.1136/bmj.n153 Published: 18 January 2021

\title{
Covid-19: US immigration enforcement flouts safety guidelines, report claims
}

\section{Owen Dyer}

US Immigration and Customs Enforcement (ICE) routinely ignores its own safety rules on covid-19, causing exceptionally high infection rates in its detention centres, according to a new report from Physicians for Human Rights (PHR). ${ }^{1}$

Social distancing was impossible in many detention centres, surfaces were left uncleaned, detainees often went without hand soap or sanitiser, and testing was often not available even for those who reported symptoms, the report said. In some centres, masks were considered a rare luxury by inmates, while in others, staff had masks but refused to wear them.

Fifty released detainees, with an average age of 36 , were interviewed by PHR using a standardised questionnaire. They had stayed at 22 centres around the US, of which 13 were private. Most said that ICE staff had consistently downplayed the severity of the pandemic, in many cases not even mentioning it to detainees.

ICE's pandemic response guidelines require staff to familiarise detainees with risks and safety procedures. But the report said that 42 out of 50 detainees had learnt of the pandemic from watching TV news, while just two were first told by ICE staff, who in some cases also sought to prevent detainees from seeing news reports.

Social distancing was an impossibility in ICE centres. Despite guidelines recommending $6 \mathrm{ft}(1.8 \mathrm{~m})$ of separation, beds averaged $2.87 \mathrm{ft}$ apart and the average number of detainees sleeping in one room was 36. "On the bunk beds, you could feel the other person's breath on you," said one detainee. "They told us to sleep head to foot after they started getting lawsuits," said another.

Detainees were routinely transferred between centres without prior testing, and added to the general population without quarantine. Transfer was one of several punitive measures used against those who complained of health risk. Sick detainees who needed isolation were often put in solitary confinement, lacking even a mattress, leading some to conceal their symptoms.

The predictable result of ICE's approach, said PHR, was an infection rate that between April and August 2020 ranged from 6 to 22 times the US average. Even this figure underestimated the true level, as testing was sparse. Positivity rates were $47 \%$ in April and $18 \%$ in August. ${ }^{2}$ As 2021 dawned, ICE was holding 16 037 detainees and had reported 8545 infections.

ICE is widely seen as a hotbed of Trump support and drew criticism in the presidential election for placing billboards showing immigration violators in swing state Pennsylvania. While many comparable agencies in Europe have released detainees to lower infection risk, ICE has ignored repeated calls from public health experts to do the same, ${ }^{3}$ and has continued to arrest and detain people within the US.

ICE has also been a global spreader of covid-19, often deporting sick people without prior testing. An investigation by the New York Times and the Marshall Project last July found 12 governments who said that ICE had sent sick people to their countries. ${ }^{4}$

This week also saw the release of a damning report by the Justice Department's inspector general into the Trump administration's family separation policy, implemented by ICE. The government pushed ahead with separating children even knowing that it lacked the mechanisms to track and reunite them with parents, the report found. ${ }^{5}$

On 14 December, acting ICE director Jonathan Fahey resigned after just weeks on the job. He was ICE's sixth leader under Trump, of whom none were confirmed by the Senate.

Meanwhile ICE detention centres around the country, like US prisons, are seeing a wave of hunger strikes by detainees protesting lax pandemic protection. ${ }^{6}$

Last week, a French teacher who has taught in elementary school in Louisiana for 19 years was released from three weeks' ICE detention wearing an ankle monitor and immediately tested positive for covid-19. Djibril Coulibaly, 50, had been in America legally on an HB1 visa when a bureaucratic error by his employer rendered him illegal. He was arrested by armed ICE agents while leaving school and told to expect deportation to his native Mali.

Coulibaly credited a local campaign by parents and neighbours for his temporary release. He was feeling weak and had lost eight pounds in detention, so was unsurprised by his diagnosis. Four men out of 43 in his dorm had tested positive in three weeks, he said. His greatest disappointment, he said, was that his infection prevented him returning to teaching or hugging his family.

Peeler K, Lee CH, Hampton K, et al. Praying for hand soap and masks: health and human rights violations in US immigration detention during the covid-19 pandemic. Physicians for Human Rights. 12 January 2021. phr.org/our-work/resources/praying-for-hand-soap-and-masks.

2 Erfani P, Uppal N, Lee CH, Mishori R, Peeler KR. Covid-19 testing and cases in immigration detention centers, April-August 2020. JAMA 2021;325:182-4.pmid: 33119038

3 Rich J, Allen S, Nimoh M. We must release prisoners to lessen the spread of coronavirus. Washington Post, 17 March 2020. www.washingtonpost.com/opinions/2020/03/17/we-must-release-prisoners-lessen-spreadcoronavirus.

Kassie E, Marcolini B. "It was like a time bomb": how ICE helped spread the coronavirus. New York Times, 10 July 2020. www.nytimes.com/2020/07/10/us/ice-coronavirus-deportation.html. 
5 Department of Justice, Office of the Inspector-General. Review of the Department of Justice's planning and implementation of its zero tolerance policy and its coordination with the Departments of Homeland Security and Health and Human Services. 14 January 2021. https://oig.jus-

tice.gov/sites/default/files/reports/21-028_0.pdf

6 Klefer E. Prison hunger strikes continue in NJ as ICE detainees fear covid. Patch. 8 January 2021. https://patch.com/new-jersey/newarknj/nj-prison-hunger-strikes-continue-essex-ice-detaineesfear-covid. 